\title{
FTIR, GC-MS Analysis and Bioactivity Studies of Withania somnifera $L$. of Nepalese Origin
}

\author{
Sangam Aryal ${ }^{1}$, Sunita Shrestha ${ }^{1}$, Anil Devkota ${ }^{1}$, Netra Lal Bhandari ${ }^{* 1}$, Ram Narayan Jha ${ }^{1}$ \\ ${ }^{1}$ Department of Chemistry, Tri-Chandra Multiple Campus, Tribhuvan University, Kathmandu, Nepal \\ *Corresponding E-mail: netra.tu.edu@gmail.com \\ (Received: March 28, 2020; Revised: June 15, 2020 \& Accepted: June 21, 2020)
}

\begin{abstract}
Present study evaluates the bio-constituents and bioactivity of extract from roots and stems of Withania somnifera (Aswagandha) of Nepalese origin. The phytochemical screening of methanol and n-hexane extracts revealed the presence of alkaloids, flavonoids, phenols, tannins, quinone, carbohydrates, resins, xanthoprotein etc. The FTIR analysis helped to confirm the functional groups of various medicinally important compounds. The DPPH percentage radical scavenging activity of methanolic and hexane extracts are found to be $3.587 \pm$ 0.004 , and $4.484 \pm 0.003 \mu \mathrm{g} / \mathrm{mL}$ respectively. The antioxidant activity of the plant goes after the number of total phenolics and flavonoids present on it. GC-MS analysis revealed the presence of more than 14 different compounds in the extract. Moreover, the methanol and hexane extract of plant showed $25.8 \%$ and $12.9 \%$ $\alpha$-glucosidase inhibitory activity respectively. The results of the study revealed the medicinal values and pharmacological significance of the plant.
\end{abstract}

Keywords: Withania somnifera, FTIR, GC-MS, antioxidant, phytochemical

\section{Introduction}

Nature has been a source of therapeutic agents and ayurvedic drugs that have been derived from natural source based on their use in traditional medicine. The increasing failure of chemotherapeutics and antibiotic resistance exhibited by pathogenic microbial infectious agents has led to the screening of several medicinal plants for their potential biological activity [1].

Withania somnifera, (L.) Dunal (Solanaceae) is one of the herbs in ayurvedic healing which is well known for its restorative behaviour. This species is a short, tender perennial shrub growing $35-75 \mathrm{~cm}$ tall bearing small, green and bell-shaped flowers. It is cultivated in many of the drier regions of India, Nepal, China and Yemen [2]. From ancient period, Ashwagandha has been used for a wide variety of conditions and prescribed to help people strength their immune system after an illness. The chemistry of $W$. somnifera has been extensively studied and over 35 chemical constituents have been identified, extracted and isolated.
Preliminary, phytochemical evaluation of the crude extract and various fractions revealed the presence of biologically active chemical constituents such as alkaloid, steroidal lactones, saponins containing an additional acyl group, flavonoids, terpenoids, tannins, glycosides, coumarins and cardiac glycosides $[1,2]$. Phytochemical studies showed that it possesses antitumor, anti-stress, immuno-modulatory, hemopoietic, neuropharmacogenic, hypolipidemic, memoryimproving effects and rejuvenating properties. It also appears to exert a positive influence on endocrine, cardio-pulmonary, and central nervous system $[2,3]$.

Significant analytical techniques such as GC-MS, NMR are necessary in order to determine plant metabolites qualitatively as well as quantitatively. A total of 62 major and minor primary and secondary metabolites from leaves and 48 from roots were identified in the previous studies. These include fatty acids, organic acids, amino acids, sugars, sterol-based compounds, phenolic acids [4]. Nearly 40 withanolides 
were isolated from $W$. somnifera root extract, still there is remaining unidentified metabolites due to very low abundance and geographical variation [5].

Biologically active withaferin A isolated from Ashwagandha is found efficacious in treatment of stress, inflammation, arthritics, hyperglycemic, and cancerous effect. The root extract of Ashwagandha also revealed antibacterial, antifungal, and antibiotic activity somewhat similar to that of Penicillin $[3,6]$. Treatment with $W$. somnifera was found to increase hemoglobin concentration, red blood cells count, platelets count, and body weight in mice [7]. In the present investigation, the phytochemical constituents, and biological activity of Nepalese origin- Withania somnifera plant extract was reported by determining antioxidant activity, estimating total phenolic and flavonoid content, and by performing the GC-MS to determine the chemical composition of the methanol extract.

\section{Materials and Methods}

\section{Plant materials collection and extract preparation}

Roots and stems of Ashwagandha were purchased from local ayurvedic medicine shop of Kathmandu valley. It was authenticated as Withania somnifera $(L$. by the National Herbarium and Plant Laboratories, Godawari, Lalitpur and the herbarium species was deposited at Botany Department, Tri-Chandra Multiple Campus, Tribhuvan University, Kathmandu, Nepal. It was rinsed with water and shade-dried for a week. The dried plant materials were grinded into the fine powdered form by mechanical grinder. The obtained powder was subjected to Soxhlet maceration with methanol at $65{ }^{\circ} \mathrm{C}$ with a solvent to sample ratio of $5: 1(\mathrm{v} / \mathrm{w})$. The process was continued to about 8 hours (for about 8-12 cycles) until solvent becomes dark colored. The extract was filtered and concentrated using rotary evaporator. The concentrated extract was weighed as a crude methanol extract. Similarly, hexane extract was also prepared. The concentrated extract was successively partitioned with n-hexane, chloroform, ethyl acetate, and n-butanol fraction respectively.

\section{Phytochemical screening}

Phytochemical screening of alkaloids, saponins, tannins, flavonoids, terpenoids, coumarins, phenols, volatile oils, sugars, quinones, carbohydrate, glucosides, fixed oils and fats were carried out for methanolic and hexane extracts as described by Edeoga [8], Trease and Evans [9], Harborne [10], Daniel [11] and Prasthith [12].

\section{Antibacterial activity}

The antibacterial screening of each plant extracts were carried out by agar well diffusion method $[13,14]$. The organisms such as one Gram positive bacteria Staphylococcus aureus (American type culture collection) ATCC 25923, two Gram negative bacteria; Escherichiacoli ATCC 25922 and Salmonella typhimurium ATCC 14028 were obtained from Department of Biotechnology (National College, Kathmandu). All micro-organism was cultured in nutrient broth (NB) and kept viable by sub-culturing in nutrient agar (NA) which were then swabbed on Muller Hamilton agar plate and with the help of micropipette, $30 \mu \mathrm{L}$ of the plant extracts. DMSO as activity control and ofloxacin as a positive control were loaded in a separate well, made using cork borer. It was incubated overnight at $37{ }^{\circ} \mathrm{C}$ for 18 to $24 \mathrm{hrs}$., and the zone of inhibition around well was measured.

Determination of total phenolic content (TPC) Follin-ciocalteau reagent was used for the total phenol determination. The $20 \mu \mathrm{L}$ plant extract, $100 \mu \mathrm{L}$ of Folin-ciocalteau reagent diluted at $1 / 10^{\text {th }}$, and $80 \mu \mathrm{L}$ of $\mathrm{Na}_{2} \mathrm{CO}_{3}(7.5 \%, \mathrm{w} / \mathrm{v})$ were mixed and incubated at 45 ${ }^{\circ} \mathrm{C}$ for 15 minutes until the blue color was developed and absorbance was taken at $765 \mathrm{~nm}$ [15]. The TPC in the plant extract was calculated by comparing with standard gallic acid and expressed as $\mathrm{mg} / \mathrm{g}$ of gallic acid equivalent (standard curve equation: $\mathrm{y}=0.0131 \mathrm{x}$ $\left.-0.0034 ; \mathrm{R}^{2}=0.9938\right)$. The estimation was carried out in triplicate.

\section{Determination of total flavonoid content (TFC)}

The total flavonoids content was calculated by the aluminum chloride colorimetric technique $[14,16]$. The $20 \mu \mathrm{L}$ plant extract was mixed with $60 \mu \mathrm{L}$ of methanol, $5 \mu \mathrm{L}$ of $10 \%$ aluminum chloride, $5 \mu \mathrm{L}$ of $(1 \mathrm{~mol} / \mathrm{L})$ potassium acetate and $110 \mu \mathrm{L}$ of distilled water which was incubated at room temperature for 30 minutes and the absorbance were taken at 415 $\mathrm{nm}$. The calibration curve was made by different concentration of quercetin dissolved in methanol. 
The content of flavonoid was expressed in terms of quercetin equivalent as $\mathrm{mg}$ of $\mathrm{Qu} / \mathrm{g}$ (the standard curve equation: $\mathrm{y}=0.0213 \mathrm{x}+0.0121 ; \mathrm{R}^{2}=0.975$ ).

\section{Antioxidant activity}

Antioxidant activity was assessed by 1,1-diphenyl-2picrylhydrazyl [DPPH] assay by slight modification in use of control in which various concentration of extracts were added to $0.5 \mathrm{~mL}$ of $0.2 \mathrm{mmol} / \mathrm{L} \mathrm{DPPH}-$ methanol solution [14]. After incubation for $30 \mathrm{~min}$ at room temperature, the absorbance was determined against a blank at $517 \mathrm{~nm}$ using multi-plate reader (EPOCH, microplate reader, Biotech). 50\% DMSO act as negative control and quercetin (Hi-Media) act as standard positive control. All experiments were performed in triplicate and was determined as:

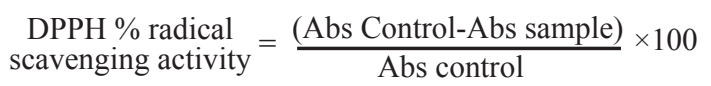

\section{Enzyme inhibition assay}

The $\alpha$-glucosidase inhibition was determined by the modified methods by Chelladurai [17]. The $20 \mu \mathrm{L}$ of $\alpha$-glucosidase enzyme and $100 \mu \mathrm{L}$ of phosphate buffered saline ( $\mathrm{pH} 6.8,0.05 \mathrm{M}$ ) and $60 \mu \mathrm{L}$ of sample were pre-incubated with various concentrations of extracts at $37{ }^{\circ} \mathrm{C}$. After the pre-incubation of $15 \mathrm{~min}$, $20 \mu \mathrm{L}$ substrate, $\mathrm{p}$-nitrophenyl-a-D-glucopyranoside was added and reaction was carried out at $37{ }^{\circ} \mathrm{C}$ for $30 \mathrm{~min}$. Enzymatic activity was calculated by measuring the absorbance at $405 \mathrm{~nm}$ on a microtiter plate spectrophotometer (Epoch 2, 96-well plate spectrophotometer, USA). Percentage inhibition was calculated as:

$$
\% \text { inhibition }=\frac{(\text { Abs Control-Abs sample })}{\text { Abs control }} \times 100
$$

\section{FTIR analysis}

Dried powder of chloroform, ethyl acetate and n-butanol fraction of methanol extract of plant materials was subjected for FTIR analysis. The powder samples were loaded in FTIR spectrometer (SHIMADZU IRPreastage-21; Japan, with a scan range from 400 to $5000 \mathrm{~cm}^{-1}$ ).

\section{Gas chromatography-mass spectrometry (GC-MS) analysis}

GC-MS analysis of the test sample was performed using GCMS-QP2010 Ultra equipped with a Rtx-
$5 \mathrm{MS}$ capillary column. $1 \mu \mathrm{L}$ of the methanol extract was injected into GC in split less injection mode where helium acted as the carrier gas at a flow rate of $4.0 \mathrm{~mL} / \mathrm{min}$. The MS operating conditions were as follows, interference temperature of $280{ }^{\circ} \mathrm{C}$, ion source temperature $280{ }^{\circ} \mathrm{C}$, mann scan (m/z)-30-600, solvent cut time 4 mins., scan speed $3333 \mathrm{amu} / \mathrm{s}$, total running time was 25 minutes.

\section{Results and Discussion}

\section{Extract preparation and phytochemical screening analysis}

The weight of hexane, and methanol extracts after completely drying over water bath are found to be 1.65 $\mathrm{g}$ and $25.22 \mathrm{~g}$ respectively. The weight of different extracts from fractional separation of methanol extract i.e. hexane, chloroform, ethyl acetate, butanol of $W$. somnifera are found to be $0.175 \mathrm{~g}, 0.245 \mathrm{~g}, 0.06$ g, $0.275 \mathrm{~g}$ accordingly.

The qualitative analysis of two different methanol and hexane extracts showed the presence of different phyto-constituents. Phenols and flavonoids are tested positive for both extracts. Alkaloids, tannins and carbohydrates are tested positive for methanol extract only which are associated with medicinal uses such as chronic diseases, glycemic responses, stimulation of lipogenesis and cytotoxicity [18]. Moreover, tannins, phenolic, flavonoids and alkaloids are the important ingredients to prevent against oxidative stress and decrease the activity of cholinesterase and alleviating the mucus secretion in the air way glands [18]. They are equally active and has medicinal and physiological significance [8]. Similarly, xanthoprotein, quinone and resins were tested positive for methanol extracts only. The identified phytochemical compounds are valuable reservoir of various bioactivity of substantial medicinal merit, and cited in many literatures [18].

\section{Anti-bacterial activity}

The results of anti-bacterial activity in this experiment showed less effective in different extracts of $W$. somnifera whereas Owais et al., 2005 has reported both aqueous as well as alcoholic extracts of the plant (root as well as leaves) possess strong antibacterial activity against a range of bacteria [19]. Similarly, Bisht et al., 2014 observed that the methanolic leaf extract of $W$. somnifera was very effective in inhibiting 

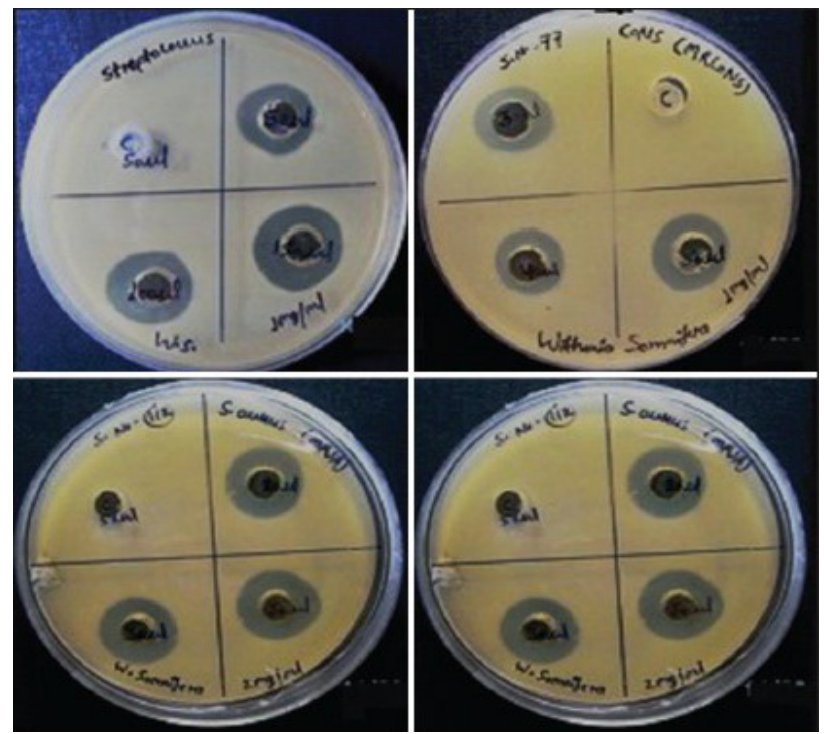

Figure 1: Zone of inhibition (in $\mathrm{mm}$ ) for different concentration of $W$. somnifera leaf extract [20]

the test pathogens including methicillin resistant Staphylococcus aureus and Enterococcus spp., with an average zone of inhibition of $20.6 \mathrm{~mm}$ and 19.4 $\mathrm{mm}$ at $2 \mathrm{mg} / \mathrm{mL}$ concentration, respectively [20].

\section{Total phenolic and flavonoid content}

In the present study, value of total phenolic content (TPC) and total flavonoid content (TFC) for methanolic extract is little bit more than hexane extract which may be due to the presence of large number of secondary metabolites in methanol crude extract. Higher phenolic content in methanol might be related to the high polarity and better solubility of phenolic compound present in plant materials than in non-polar hexane [21].

Table 1: Total phenolic content of extracts of $W$. somnifera

\begin{tabular}{|c|c|c|c|c|}
\hline $\begin{array}{l}\text { Conc. of } \\
\text { gallic acid } \\
(\mu \mathrm{g} / \mathrm{mL})\end{array}$ & $\begin{array}{l}\text { Abs. } \\
\text { of gallic } \\
\text { acid }\end{array}$ & $\begin{array}{l}\text { Co n c o f } \\
\text { test sample } \\
(\mu \mathrm{g} / \mathrm{mL})\end{array}$ & $\begin{array}{l}\text { Abs.of } \\
\text { hexane } \\
\text { extract }\end{array}$ & $\begin{array}{l}\text { Abs. of } \\
\text { methanol } \\
\text { extract }\end{array}$ \\
\hline 10 & 0.134 & \multirow{8}{*}{20} & \multirow{8}{*}{0.130} & \multirow{8}{*}{0.145} \\
\hline 15 & 0.206 & & & \\
\hline 20 & 0.251 & & & \\
\hline 25 & 0.291 & & & \\
\hline 30 & 0.382 & & & \\
\hline 35 & 0.47 & & & \\
\hline 40 & 0.510 & & & \\
\hline 45 & 0.600 & & & \\
\hline \multicolumn{5}{|c|}{$\begin{array}{l}\text { Total phenolic content: } 9.66 \mathrm{mg} \text { of } G A E / g \text { in hexane and } \\
10.8 \mathrm{mg} \text { of } G A E / g \text { in methanol extract }\end{array}$} \\
\hline
\end{tabular}

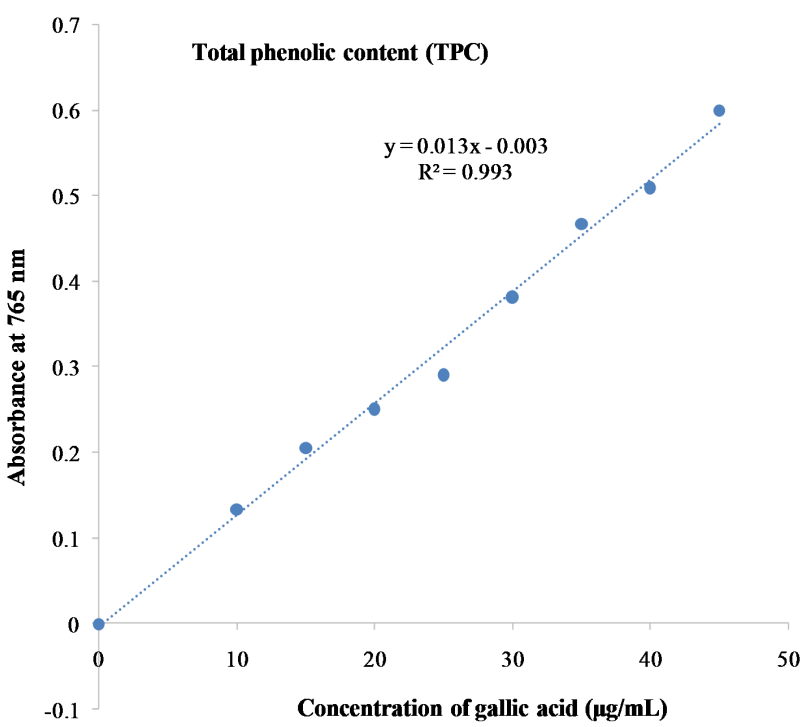

Figure 2: Graph representing the regression curve of gallic acid

The results of TPC in table 1 and TFC in table 2 are expressed in plot as Figure 2, and Figure 3 respectively.

Table 2: Total flavonoid content of extracts of $W$. somnifera

\begin{tabular}{|c|c|c|c|c|}
\hline $\begin{array}{l}\text { Conc. of } \\
\text { quercetin } \\
(\mu \mathrm{g} / \mathrm{mL})\end{array}$ & $\begin{array}{l}\text { Abs. of } \\
\text { quercetin }\end{array}$ & $\begin{array}{l}\text { Conc. of } \\
\text { test sample } \\
(\mu \mathrm{g} / \mathrm{mL})\end{array}$ & $\begin{array}{l}\text { Abs. of } \\
\text { hexane } \\
\text { extract }\end{array}$ & $\begin{array}{l}\text { Abs. of } \\
\text { methanol } \\
\text { extract }\end{array}$ \\
\hline 10 & 0.191 & \multirow{4}{*}{500} & \multirow{4}{*}{0.076} & \multirow{4}{*}{0.082} \\
\hline 20 & 0.479 & & & \\
\hline 30 & 0.720 & & & \\
\hline 40 & 0.801 & & & \\
\hline \multicolumn{5}{|c|}{$\begin{array}{l}\text { Total flavonoid content: } 3.05 \mathrm{mg} \text { of Qu/g for hexane and } \\
3.33 \mathrm{mg} \text { of } Q u / g \text { for methanol extract }\end{array}$} \\
\hline
\end{tabular}

Secondary metabolites show immunological, antioxidant, pharmacological and insecticidal activity. They also serve as enzyme inhibitors, mineral scavengers and autoregulators [22]. Earlier studies showed higher TPC in methanol extract $(33.1 \pm 0.82 \mathrm{mg}$ $\mathrm{GAE} / \mathrm{mL})$ but lower TFC content $(1.86 \pm 0.01 \mathrm{mg} \mathrm{Qu} /$ $\mathrm{mL}$ ) [23] than this study that showed $10.8 \mathrm{mg} \mathrm{GAE} / \mathrm{g}$ (TPC) and $3.33 \mathrm{mg}$ of Qu/g (TFC) in methanol extract. According to study based on phytochemical content analysis showed $180.80 \pm 0.01 \mathrm{mg} / 100 \mathrm{mg}$ gallic acid equivalent phenolic content whereas $136.97 \pm 0.01$ $\mathrm{mg} / 100 \mathrm{mg}$ quercetin equivalent flavonoid content in methanol root extract of $W$. somnifera [18]. The results suggest that the phenols are the important components of the extraction. Literatures suggest that the antioxidant property in Ashwagandha is mainly due to its high phenolic content. 


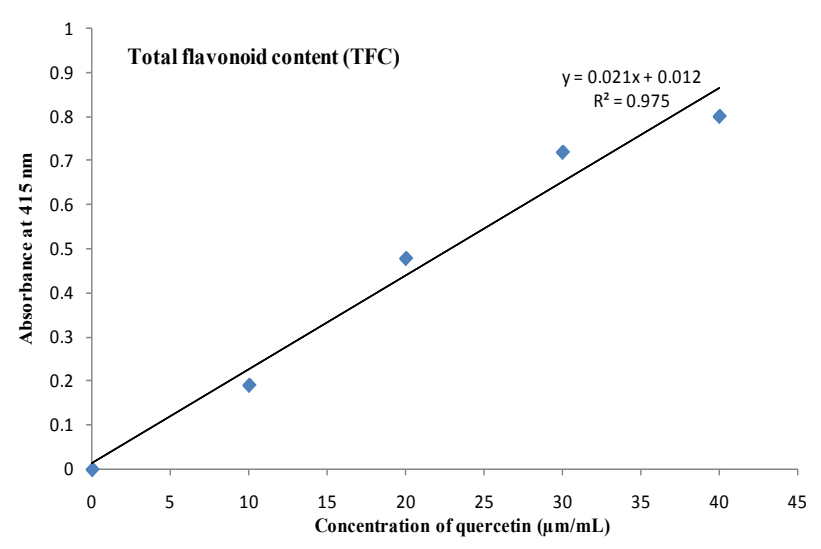

Figure 3: Graph representing regression curve of quercetin

\section{Antioxidant property}

The DPPH assay is based on the capacity of an antioxidant to donate hydrogen or an electron to DPPH radical, which is stable free radical with deep purple color. When an odd electron become paired in presence of free radical scavenger of antioxidant agent, DPPH radicals get reduced to corresponding hydrazine, DPPH-H form and the solution gets decolorized from its initial deep purple color into colorless product, resulting a decrease in absorbance at $517 \mathrm{~nm}$ band and is proportional to the concentration of antioxidant. The percentage inhibition of methanol and hexane extract is presented in Figure 4.

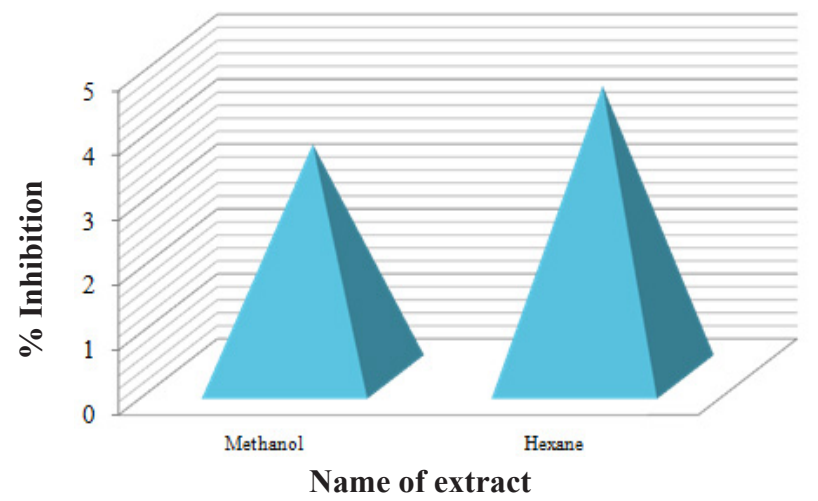

Figure 4: Percentage inhibition of methanol and hexane extracts of $W$. somnifera against $\alpha$-glucosidase enzyme

This study showed $3.587 \pm 0.004$, and $4.484 \pm 0.003$ $\mu \mathrm{g} / \mathrm{mL}$ radical scavenging activity of methanolic and hexane extracts respectively. This data that expressed the methanol, and hexane extract showed certain DPPH percentage inhibition which is related to the phenolic and flavonoid content in extracts. Flavonoids show their antioxidant action through scavenging or chelating process whereas phenols act as reducing agent, hydrogen donors, metal chelator and radical scavenger due to their hydroxyl groups [18]. Previous study on antioxidant study of indigenous $W$. somnifera [24] showed higher antioxidant activity in methanol extract $12 \mu \mathrm{g} / \mathrm{mL}$ that might be because of the use of higher concentration of extract. Literature review confirmed that methanol extract of indigenous Withania species displayed promising antioxidant activity of the evidence by DPPH assay compared to this study [22].

\section{Enzyme inhibition assay}

The methanolic and aqueous extract of $S$. oblonga showed effective inhibition against $\alpha$-glucosidase ranging from $8.92 \%$ to $68.51 \%$ at a concentration of 10 to $100 \mathrm{mg} / \mathrm{mL}$ [17]. Apart from this, this study showed only $25.8 \%$ and $12.9 \%$ percentage inhibition of $\alpha$-glucosidase in methanol and hexane extracts of $W$. somnifera. The result is in good acquaintance with the enzyme inhibition by $C$. grandis and $G$. lactiferum [25]. The enzyme alpha amylase and alpha glucosidase is responsible for the breakdown of carbohydrates into glucose. The certain percentage of inhibitory activity of methanol extract towards alpha glucosidase can be used to reduce the blood glucose level and use as a medicine to cure diabetic patients. This is due to the availability of phytochemical constituents like tannins, terpenoids and flavonoids. Tannins and flavonoids have potential inhibitory effects on alpha amylase and alpha glucosidase [17].

\section{FTIR analysis of extracts}

The FTIR spectra of chloroform, ethyl acetate, and butanol extracts of $W$. somnifera samples are recorded in between 4000 to $400 \mathrm{~cm}^{-1}$ and presented in Figure 5. In FTIR spectrum, broad peaks at $3325.28 \mathrm{~cm}^{-1}$, $3294.42 \mathrm{~cm}^{-1}$ and $3286.70 \mathrm{~cm}^{-1}$ represent phenolic and $-\mathrm{OH}$ group, $2924.09 \mathrm{~cm}^{-1}$ and $2854.65 \mathrm{~cm}^{-1}$ are associated with saturated -CH stretching, $1689.64 \mathrm{~cm}^{-}$ ${ }^{1}, 1674.21 \mathrm{~cm}^{-1}$ and $1666.50 \mathrm{~cm}^{-1}$ represent aromatic $\mathrm{C}=\mathrm{C}$ group system, $1373.32 \mathrm{~cm}^{-1}, 1334.74 \mathrm{~cm}^{-1}$ and $1327.03 \mathrm{~cm}^{-1}$ signify C-H bending, $1265.30 \mathrm{~cm}^{-1}$ and $1257.59 \mathrm{~cm}^{-1}$ represent Ar-O stretching, $1026.13 \mathrm{~cm}^{-1}$ indicates $\mathrm{CH}_{3}-\mathrm{O}$ group, $864.11 \mathrm{~cm}^{-1}$ shows aromatic benzene ring, and $416.62 \mathrm{~cm}^{-1}$ as S-S stretching. 

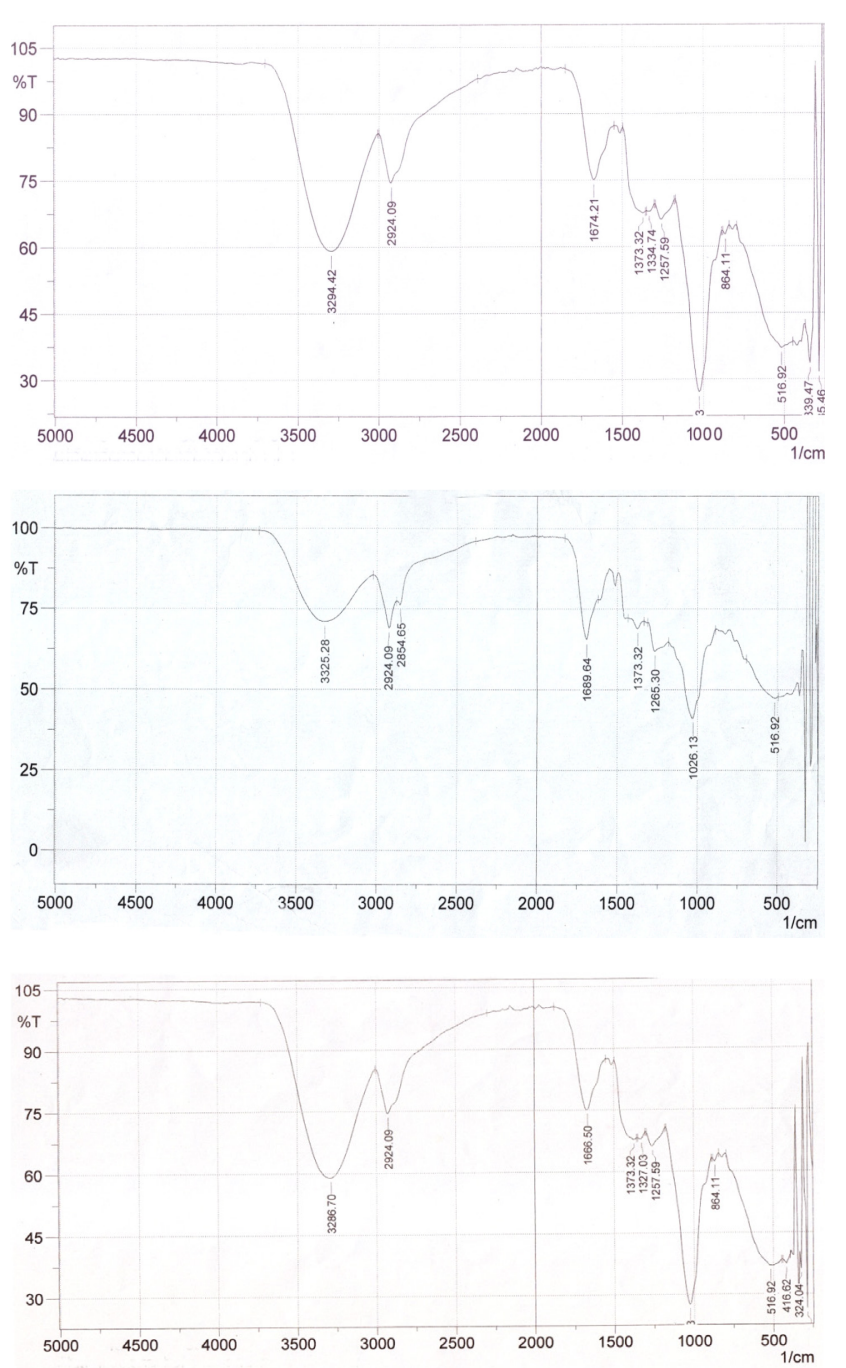

Figure 5: FTIR spectra of a) chloroform, b) ethyl acetate, and c) butanol extract of $W$. somnifera

Likewise, the peak at $1026.13 \mathrm{~cm}^{-1}$ corresponds the withanolide ring bond and flavonoid like structures [26].

\section{GC-MS analysis of extract}

The chromatograms of methanol extract obtained as in Figure 6 with different retention times showed 14 peaks that indicate the presence of 14 major phyto-constituents. The identified compounds on the

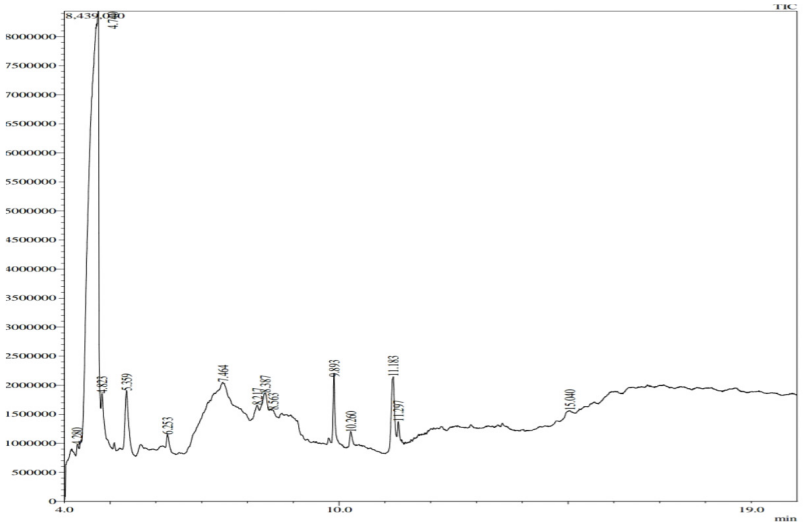

Figure 6: GC-MS chromatogram of methanol extract of W. somnifera

basis of retention time are presented in table 3 and medicinal importances of some bioactive compounds are mentioned in table 4 . The results revealed that 2-Furan carboxaldehyde, 5-(hydroxymethyl) was found as the one major component of the methanol extract and several other minor components.

Mass spectrum of a compound reported at retention time $9.893 \mathrm{~min}$. shows the different fragmentations with the base peak at 73.05. The recorded spectrum is compared with the spectrum available in software database and found match with the mass spectrum of pentadecanoic acid which has a base peak 73 and other fragmentation peak. Analysis of chromatogram peak at RT 9.893 min., with base peak 73 and molecular ion at $\mathrm{m} / \mathrm{z} 242$ suggested the molecular formula $\mathrm{C}_{15} \mathrm{H}_{30} \mathrm{O}_{2}$ and concluded it to be pentadecanoic acid. Scheme 1 displays the fragmentation pattern of pentadecanoic acid.

Similarly, the entire spectrum obtained was compared with the available software database that helps to propose structure with molecular formula. Chromatogram and structure of some important chemical constituents of methanolic extract of $W$. somnifera from GC-MS analysis are represented in Figure 7.
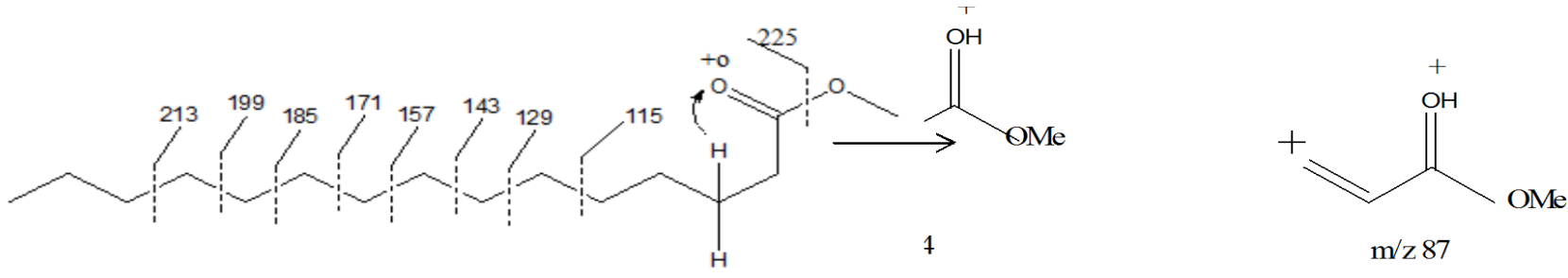

Scheme 1: Fragmentation pattern of pentadecanoic acid 

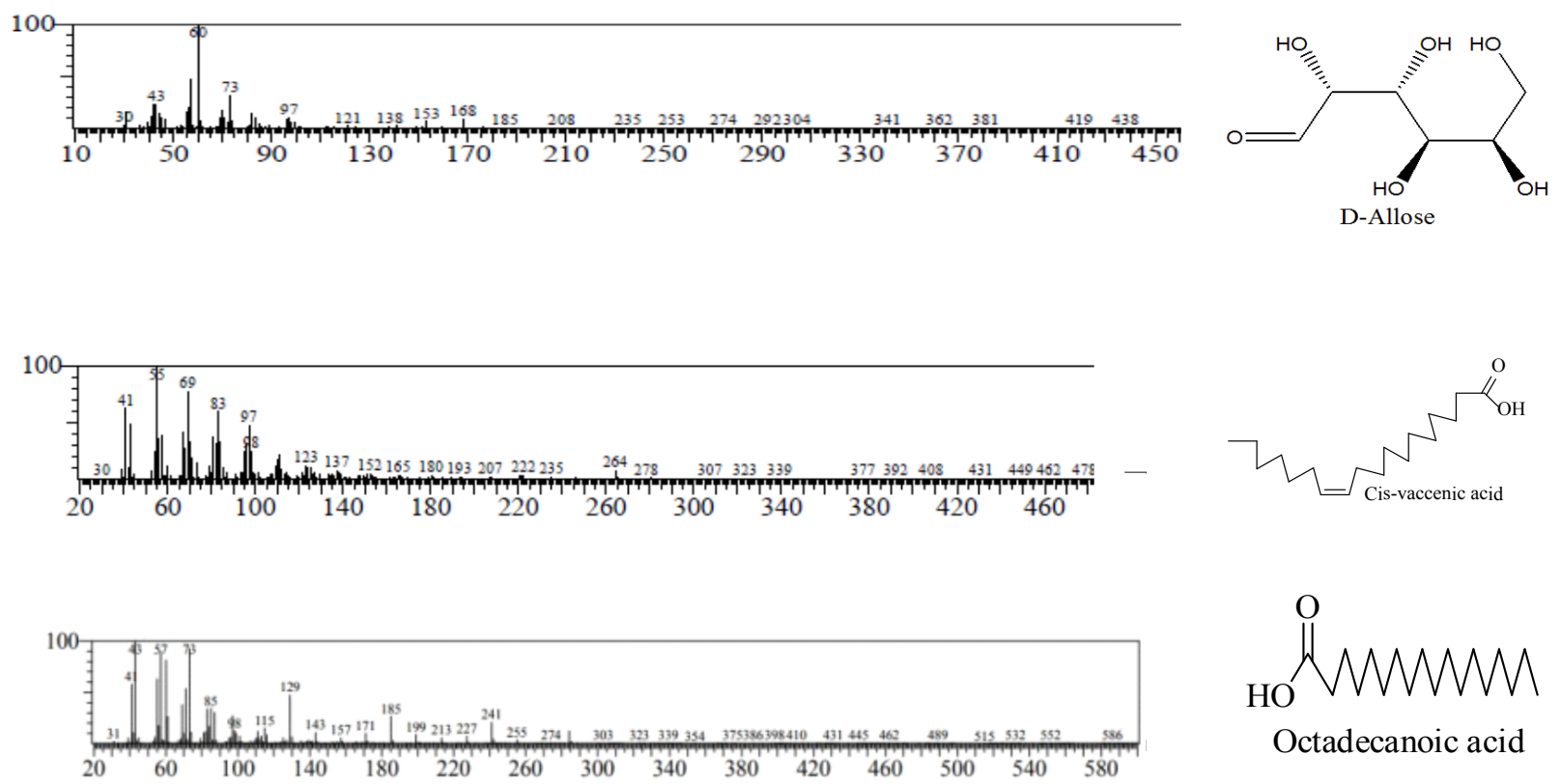

Octadecanoic acid

Figure 7: Mass spectrum of some fractions in chromatogram corresponding to the structure of D-allose, cis-vaccenic acid, and octadecanoic acid respectively

Table 4: Phytochemical compounds shown by GC-MS of W. somnifera

\begin{tabular}{|c|c|c|c|c|c|}
\hline $\mathbf{R T}$ & $\%$ Area & Name & MW & M. formula & Base \\
\hline 4.280 & 0.70 & 3-Methyl-2-furoic acid & 126 & $\mathrm{C}_{6} \mathrm{H}_{6} \mathrm{O}_{3}$ & 126.05 \\
\hline 4.740 & 59.66 & $\begin{array}{l}\text { 2-Furancarboxaldehyde, } \\
\text { 5-(hydroxymethyl)- }\end{array}$ & 126 & $\mathrm{C}_{6} \mathrm{H}_{6} \mathrm{O}_{3}$ & 97.00 \\
\hline 4.823 & 3.03 & 1,2,3-Propanetriol, 1-acetate & 134 & $\mathrm{C}_{5} \mathrm{H}_{10} \mathrm{O}_{4}$ & 43.00 \\
\hline 5.359 & 3.05 & $\begin{array}{l}\text { N-Nitroso-2-ethyl-1,3- } \\
\text { tetrahydrooxazine }\end{array}$ & 144 & $\mathrm{C}_{6} \mathrm{H}_{12} \mathrm{~N}_{2} \mathrm{O}_{2}$ & 42.00 \\
\hline 6.253 & 0.35 & $\begin{array}{l}\text { 3-Bromo-5,5-dimethyl- } \\
\text { cyclohex-2-enol }\end{array}$ & 204 & $\mathrm{C}_{8} \mathrm{H}_{13} \mathrm{BrO}$ & 125.05 \\
\hline 7.464 & 21.75 & D-Allose & 180 & $\mathrm{C}_{6} \mathrm{H}_{12} \mathrm{O}_{6}$ & 60.00 \\
\hline 8.217 & 1.53 & $\begin{array}{l}\text { 3-hydroxy-4-methyl-2,5- } \\
\text { pyridine dimethanol }\end{array}$ & 169 & $\mathrm{C}_{8} \mathrm{H}_{11} \mathrm{NO}_{3}$ & 169.10 \\
\hline 8.387 & 2.43 & $\begin{array}{l}\text { 1,4-Dioxaspiro }[4,5] \text { decane } \\
\text { (E)-2,3-dimethyl-7-t-butyl- }\end{array}$ & 226 & $\mathrm{C}_{14} \mathrm{H}_{26} \mathrm{O}_{2}$ & 169.05 \\
\hline 8.563 & 0.67 & 3,4-Dichloroatropine & 357 & $\mathrm{C}_{17} \mathrm{H}_{21} \mathrm{Cl}_{2} \mathrm{NO}_{3}$ & 124.10 \\
\hline 9.893 & 1.98 & Pentadeconoic acid & 242 & $\mathrm{C}_{15} \mathrm{H}_{30} \mathrm{O}_{2}$ & 73.05 \\
\hline 10.260 & 0.54 & $\begin{array}{l}\text { 3-(Furan-2-ylmethyl-methyl- } \\
\text { sulfamoyl)-benzoic acid }\end{array}$ & 295 & $\mathrm{C}_{13} \mathrm{H}_{13} \mathrm{NO}_{5} \mathrm{~S}$ & 81.05 \\
\hline 11.183 & 3.40 & Cis-Vaccenic acid & 282 & $\mathrm{C}_{18} \mathrm{H}_{34} \mathrm{O}_{2}$ & 55.00 \\
\hline 11.297 & 0.80 & Octadecanoic acid & 284 & $\mathrm{C}_{18} \mathrm{H}_{36} \mathrm{O}_{2}$ & 43.05 \\
\hline 15.040 & 0.07 & $\begin{array}{l}\text { 1-Hydroxymethyl-7,7- } \\
\text { dimethyl-bicyclo [2.2.1] } \\
\text { heptanes-2,3-dione }\end{array}$ & 182 & $\mathrm{C}_{10} \mathrm{H}_{14} \mathrm{O}_{3}$ & 85.10 \\
\hline
\end{tabular}


Table 5: Bio-activity of the compounds identified in methanol extracts of $W$. somnifera from GCMS analysis

\begin{tabular}{ll}
\hline Compound name & Pharmacological activity [27-34] \\
\hline $\begin{array}{l}\text { 2-Furancarboxaldehyde, } \\
\text { 5-(hydroxymethyl) }\end{array}$ & Stop neuron apoptosis \\
D-allose & $\begin{array}{l}\text { Promoter of hexose transport curb, } \\
\text { transport ligand in hexose transport } \\
\text { system of adipose fat cells }\end{array}$ \\
& $\begin{array}{l}\text { Used in pharmaceutical tablets and } \\
\text { capsules, antiviral, antarthritic, anti- } \\
\text { Octadecanoic acid/ }\end{array}$ \\
inflammatory, lower LDL cholesterol \\
Cis-vaccenic acid & $\begin{array}{l}\text { Anti-carcinogenic, inhibit telomerase } \\
\text { enzyme }\end{array}$ \\
\hline
\end{tabular}

The bioactive compounds present in $W$. somnifera supports its medicinal value, and have been proved against several diseases. So, $W$. somnifera is considered as a wonder plant with varieties of medicinal potentials.

\section{Conclusion}

Ashwagandha of Indian origin were mostly studied in literatures but in this investigation, biological study of Nepalese origin Ashwagandha is carried out. This study revealed the antioxidant property via DPPH scavenging activity which further found to beassociated with the total phenolic and flavonoid content present in the plant. The presence of phenols, flavonoids along with other secondary metabolites alkaloids, tannins, resin are confirmed by phytochemical analysis. The existence of these compounds indicated the different biological activity of $W$. somnifera. Methanol extract showed $\alpha$-glucosidase inhibitory activity which accounts its efficacy as anti-diabetic agent that is also due to the presence of tannins and flavonoid like bioactive compounds. Moreover, The FTIR spectroscopy of the chloroform, butanol and ethyl acetate extracts indicated the presence of functional groups of bioactive compounds of the plant which were determined by GCMS analysis.

The presence of various bioactive compounds justifies the use of the plant parts for various ailments by traditional practioners. Besides, in case of natural product it is always not necessary that the dosage of individual compound provide proper drug efficacy, sometimes dosage of combined compounds show higher efficacy to individual one. However, isolation of active constituents will definitely give fruitful results.
It was concluded that phyto-constituents present in W. somnifera of Nepalese origin, is responsible for antioxidant and enzyme inhibition activity.

\section{Acknowledgement}

The authors would like to thank Department of Biotechnology, National College, Kathmandu, Nepal for providing microbial strains.

\section{References}

1. S. P. Rout, K. A. Choudary, D. M. Kar, L. Das, and A. Jain, Plants in traditional medicinal systemfuture source of new drugs, International Journal of Pharmacy and Pharmaceutical Sciences, 2009, 1(1), 1-23.

2. G. Uddin, S. Gul, and A. Rauf, Preliminary phytochemical screening, in vitro antimicrobial and antioxidant evaluation of Withania somnifera Dunal, World Applied Sciences Journal, 2013, 27(5), 562-565.

3. L. C. Mishra, B. B. Singh, and S. Dagenais, Scientific basis for the therapeutic use of $W$. somnifera (ashwagandha): a review, Alternative Medicine Review, 2000, 5, 334-346.

4. S. Chatterjee, S. Srivastava, A. Khalid, N. Singh, R. S. Sangwan, O. P. Sidhu, R. Roy, C. L. Khetrapal, and R. Tuli, Comprehensive metabolic finger printing of Withania somnifera leaf and root extracts, Phytochemistry, 2010, 71, 1085-1094.

5. M. K. Trivedi, P. Panda, and S. Jana, Metabolite profiling in Withania somnifera roots hydroalcoholic extract using LC/MS, GC/MS and NMR spectroscopy, Chemistry and Biodiversity, 2017, 14(3). DOI:10.1002/cbdv.201600280.

6. S. K. Bhattacharya, and A. V. Muruganandam, Adaptogenic activity of Withania somnifera: an experimental study using a rat model of chronic stress, Pharmacology Biochemistry and Behavior, 2003, 75(3), 547-555.

7. M. Ziauddin, N. Phansalkar, P. Patki, S. Diwanay, and B. Patwardhan, Studies on the immunomodulatory effect of Asgandh, Journal of Ethnopharmacology, 1996, 50(2), 69-76. 
8. H. O. Edeoga, D. E. Okwu, and B. O. Mbaebie, Phytochemical constituents of some Nigerian medicinal plants, African Journal of Biotechnology, 2005, 4(7), 685-688.

9. G. E. Trease, and W. C. Evans, A Text Book of Pharmacognosy, $14^{\text {th }}$ Ed., Bailliere Tindall Ltd, London, 1996, 832.

10. J. B. Harborne, Phytochemical Methods, $2^{\text {nd }}$ Ed., Chapman and Hall, New York, 1984, 3,100-117.

11. M. Daniel, Medicinal Plants Chemistry and Properties, Science publishers, Enfield, NH, U.S.A, 2006, 107.

12. K. T. R. Prashith, K. N. Rakesh, N. Dileep, J. Syed, G. M. Pavithra, S. Junaid, V. H. Megha, S. S. Gunaga, and H. L. Raghavendra, Antimicrobial and antioxidant activity of Anaphalis lawii (J. Hooker) Gamble Science, Technology and Arts Research Journal, 2012, 1(3), 8-16.

13. F. Opoku, and O. Akoto, Antimicrobial and phytochemical properties of Alstonia boonei extracts, Organic Chemistry Current Research, 2014, 4(1), 1-4.

14. F. Medini, H. Fellah, R. Ksouri, and C. Abdelly, Total phenolic, flavonoid and tannin contents and antioxidant and antimicrobial activities of organic extracts of shoots of the plant Limonium delicatulum, Journal of Taibah University for Science, 2014, 89(3), 216-224.

15. J. Javanmardi, C. Stushnoff, E. Locke, and J. M. Vivanco, Antioxidant activity and total phenolic content of Iranian Ocimum accessions, Food Chemistry, 2012, 83(4), 547-550.

16. E. Joubert, M. Manley, and M. Botha, Evaluation of spectrophotometric methods for screening of green rooibos (Aspalathus linearis) and green honeybush (Cyclopia genistoides) extracts for high levels of bio-active compounds, Phytochemical Analysis, 2008, 19(2),169-178.

17. G. R. M. Chelladurai, and C. Chinnachamy, Alpha amylase and alpha glucosidase inhibitory effects of aqueous stem extract of Salacia oblonga and its GC-MS analysis, Brazilian Journal of Pharmaceutical Sciences, 2018, 54(1), 1-10.
18. D. Chaudhuri, N. B. Ghate, R. Sarkar, and N. Mandal, Phytochemical analysis and evaluation of antioxidant and free radical scavenging activity of Withania somnifera root, Asian Journal of Pharmaceutical and Clinical Research, 2012, 5(4), 193-199.

19. M. Owasi, K. S. Sharad, A. Shehbaz, and M. Saleemuddin, Antibacterial efficacy of Withania somnifera (Ashwagandha) an indigenous medical plant against experimental murine salmonellosis, Phytomedicine, 2005, 12(5), 229-235.

20. P. Bisht, and V. Rawat, Antibacterial activity of Withania somnifera against Gram positive isolates from pus sample, $A Y U$ : An International Quarterly Journal of Research in Ayurveda, 2014, 35(3), 330-332.

21. N. Babber, H. S. Oberoi, S. K. Sandu, and V. $\mathrm{K}$. Bhargav, Influence of different solvents in extraction of phenolic compounds from vegetable residues and their evaluation as natural sources of antioxidants, Journal of Food, Science and Technology, 2014, 51(10), 2568-2575.

22. L. C. Vining, Functions of secondary metabolites, Annual Review of Microbiology, 1990, 44, 395427.

23. N. Raj, A. Agarwal, and N. Chaturvedi, In vitro study on total phenols, flavonoids content and DPPH activity of Withania species, International Journal of Environment, Agriculture and Biotechnology, 2017, 2(2), 946-950.

24. R. K. Paul, H. Kabir, U. K Chowdhury, M. S. Rahaman, M. F. Ahmad, and D. K. Bhattacharjya, In vitro study of antioxidant activity of Withania somnifera root, International Journal of Advanced Research in Chemical Science, 2016, 3(3), 45-56.

25. J. Poongunran, H. K. I. Perera, W. I. T. Fernando, L. Jayasinghe, and R. Sivakanesan, $\alpha$-Glucosidase and $\alpha$-Amylase inhibitory activities of nine Sri Lankan antidiabetic plants, British Journal of Pharmaceutical Research, 2015, 7(5), 365-374.

26. V. S. A. Kumar, K. V. D. Babu, R. Salini, J. Eapen, and M. S. Deepa, FTIR spectroscopy 
data as a fingerprint of $W$. somnifera root tissue: A case study with accessions of the species from Kerala, South India, Indo-American Journal of Pharmaceutical Research, 2016, 6, 5748-5756.

27. N. Z. Alias, N. Kamisah, and M. Ishak, Chemical constituents and bioactivity studies of Ardisia elliptica, The Open Conference Proceedings Journal, 2014, 5, 1-4.

28. L. Growther, K. Sukirtha, N. Saritha, and A. S. Niren, Antibacterial activity of Punica granatum peel extracts against Shiga toxin producing E. coli, International Journal of Life Science Biotechnology and Pharma Research, 2012, 1(4), 164-172.

29. H. Gu, Z. Jiang, M. Wang, H. Jiang, F. Zhao, X. Ding, B. Cai, and Z. Zhan, 5-hydromethylfurfural from wine processed Fructus corni inhibits hippocampal neuron apoptosis, Neural Regen Research, 2013, 8(28), 2605-2614.

30. P. Revathi, T. Jeyaseelansenthinath, and P. Thirumalaikotundhusubramaian, Preliminary phytochemical screening and GC-MS analysis of ethanolic extract of Mangrove plant-Bruguiera cylindrical (Rhizho) L, International Journal of Pharmacognosy and Phytochemical Research, 2014-15, 6(4), 729-740.
31. S. Vijayakumar, S. Chandrasekar, and S. Prabhu, Screening of ethnomedicinal plants for antibacterial activity, International Journal of Medicine and Pharmaceutical Sciences, 2013, 3(2), 11-20.

32. M. S. Manorenjitha, A. K. Norita, S. Norhisham, and M. Z. Asmawi, GC-MS analysis of bioactive components of Ficus religiosa (Linn.) stem, International Journal of Pharma and Biosciences, 2012, 4(2), 99-103.

33. S. Sharma, A. Kumari, and M. Sharma, Comparative GC-MS analysis of bioactive compounds in methanolic extract of Calotropis gigantea (L) W. T. Aiton leaf and latex, International Journal of Pharmacognosy and Phytochemical Research, 2016, 8(11), 18231827.

34. S. P. Arockia, M. Amaladasan, J. Gowri, V. Dharmalingaon, L. Prabha, and R. Rajendran, GC-MS analysis of different solvent crude extracts from the coastal region of Wedeliabi flora, International Research Journal of Biological Sciences, 2015, 4(5), 23-30. 